\title{
Suzuki Eğitiminin Flüt Eğitimi Çerçevesinde Suzuki Eğitimcileri Tarafından Değerlendirilmesi ${ }^{1}$
}

\section{An Evaluation on The Suzuki Training within The Frame of Flute Training by Suzuki Educators}

\section{Erdal Ergüven}

Yüksek Lisans Öğrencisi, Muğla S1tkı Koçman Üniversitesi Eğitim Fakültesi Güzel Sanatlar Eğitimi Bölümü Müzik Eğitimi Ana Bilim Dalı

email: erdalerguvenn@gmail.com (DORCID ID: https://orcid.org/0000-0003-4421-4222

\section{Gülce Coşkun Şentürk}

Dr. Öğr. Üyesi, Muğla Sitkı Koçman Üniversitesi Eğitim Fakültesi Güzel Sanatlar Eğitimi Bölümü Müzik Eğitimi Ana Bilim Dalı

email: gulcecoskun@mu.edu.tr (DORCID ID: https://orcid.org/0000-0003-4011-2229

${ }^{1}$ Bu çalışma Muğla Sıtkı Koçman Üniversitesi Eğitim Bilimleri Enstitüsü Güzel Sanatlar Eğitimi Anabilim Dalı Müzik Eğitimi Bilim Dalı Yüksek Lisans Programında yürütülen "Seminer dersi” kapsamında hazırlanan araştırmanın genişletilerek hazırlanmış halidir

\section{Atıf (APA 6)/To cite this article}

Ergüven, E., \& Coşkun Şentürk, G. (2019). Suzuki eğitiminin flüt eğitimi çerçevesinde Suzuki eğitimcileri tarafindan değerlendirilmesi. Atatürk Üniversitesi Güzel Sanatlar Enstitüsü Dergisi, 43, 115-127. doi: https://doi.org/10.35247/ataunigsed.582637

Makale Gönderim Tarihi/Received: 26/06/2019

Makale Kabul Tarihi/Accepted: 29/09/2019

Makale Yayın Tarihi/Published: 26/10/2019

Research Article/Araștırma Makalesi

\section{$\ddot{\mathbf{O} z}$}

Bu çalıșma, Suzuki yönteminin flüt eğitimi çerçevesinde Suzuki eğitimcileri tarafından değerlendirilmesini amaçlamaktadır. Calıșmada; nitel araștırma yöntemlerinde kullanılan durum çalışması deseni kullanılmış ve bu doğrultuda yarı yapılandırılmış görüssme formu kullanılarak veriler elde edilmiștir. Araștırma, ik çalıșma grubu ile gerçekleștirilmiștir. Araștırmanın ilk çalıșma grubu Avrupa Suzuki Birliği'ne (ESA) bağlı olarak 2008 yılında Türkiye'de kurulmus olan Suzuki Müzik Eğitimi Derneğine bağlı ülkemizdeki 7 Suzuki eğitimcisinden oluşurken ikinci çalışma grubu; Avrupa Suzuki Birliği' ne (ESA) bağlı Avrupa'daki 6 Suzuki flüt eğitimcisinden oluşmaktadır. Görüşmeler sonucunda elde edilen verilerin çözümlenmesinde ise betimsel analiz kullanılmıstır. Calıșmanın sonucunda eğitimciler, Suzuki yönteminin önemli bir çalgı eğitimi yaklaşımı olduğunu, yöntemin sistematiği, ișleyiși ve felsefesi yönüyle diğer çalgı eğitimi yaklaşımlarından farklılık gösterdiğini, Suzuki yöntemiyle erken yaşta çalgı çalan başarılı öğrenciler yetiştirdiklerini, Suzuki eğitiminin ülkemizde yaygınlașarak flüt eğitiminde de uygulanması gerektiği belirtmişlerdir.

Anahtar kelimeler: Flüt, Flüt eğitimi, Suzuki yöntemi, Suzuki flüt, Suzuki flüt eğitimi

\begin{abstract}
The aim of this study is to evaluate the Suzuki method within the frame of flute training by Suzuki educators. In this context, this study is important due to the determination of the place of the Suzuki flute training in our country and being the first study to be conducted in this field in the literature. In the study, the case study pattern from qualitative research methods was used and data were accordingly obtained through the semi-structured interview form. The research was carried out with two study groups. While the first study group consists of 7 Suzuki educators in our country from the Suzuki Music Training Foundation, which was established in Turkey in 2008 in connection with the European Suzuki Association (ESA), the second study group is comprised of 6 Suzuki flute educators from the European Suzuki Association (ESA). The descriptive analysis was used for analyzing the data obtained as a result of the interviews. As a result of the study, educators stated that the Suzuki method is a significant approach for instrumental training, it differed from other instrumental training approaches with its systematics, process and philosophy, they raised successful students who play an instrument at an early age through the Suzuki method, and the Suzuki training should be popularized and applied to flute training in our country.
\end{abstract}

Keywords: Flute, Flute training, Suzuki method, Suzuki flute, Suzuki flute training

\section{Giriș}

Bilişsel, devinişsel ve duyuşsal becerilerin yoğun bir biçimde ilişkili ve iç içe olduğu müzik eğitiminde, öğrencilere teknik ve müzikal becerinin kazandırılması amaçlanmaktadır. Bu bağlamda çalgı eğitimi müzik eğitiminin önemli bir boyutunu oluşturmaktadır.

“Çalg1 eğitimi; önceden belirlenmiş amaçlar doğrultusunda, programlı bir şekilde, yüz yüze eğitim yaklaşımı esas alınarak yürütülen ve bireye özgü niteliklere uygun olarak düzenlenen, çalgı öğretim süreci olarak tanımlanabilir. $\mathrm{Bu}$ süreç içinde öğrenci, çalgı hakkında bilişsel, devinişsel ve duyuşsal öğrenme alanlarında temel bilgi ve beceriler ile tüm teknik davranışları kazanmakta ve belirlenen hedefleri çalgısı aracıllı̆ıyla gerçekleştirmektedir" (Yalçınkaya, Eldemir ve Sönmezöz, 2014, s. 1584). 
Ülkemizde çalgı eğitimi; müzik eğitimi anabilim dalları, güzel sanatlar fakülteleri müzik bölümleri, konservatuarlar, halk eğitim merkezleri, örgün eğitim kurumları ve bazı özengen müzik eğitimi veren özel kurumlar tarafından yürütülmektedir. Her kurumun farklı hedef kitlesi ve öğretim yöntemi bulunsa da hepsi bireyin müziksel bilgileri anlamasını, kavramasını ve içselleştirerek sergilemesini amaçlamaktadır. Bu amaç doğrultusunda farklı öğretim yöntemleri ve stratejilerinin geliştirilmesi, birbirinden farklı özelliklere ve öğrenme becerine sahip bireylerin başarıya daha çabuk ulaşmasını kolaylaştırmaktadır. Literatür bu bağlamda incelendiğinde, farklı müzik öğretim yöntemine ulaşmak mümkündür. Suzuki, Orff, Kodaly vb. birçok yaklaşım son yıllarda eğitimciler tarafından ele alınmakta ve irdelenmektedir. Yapılan çalışmalar ile bu yaklaşımlara olan ilgi artmış, öğretmenler, veliler ve öğrenciler tarafından tercih edilmeye başlanmıştır. Bu kapsamda bahsi geçen yaklaşımların eğitim öğretim faaliyetlerini düzenlemek adına ülkemizde çeşitli merkezler kurulmaya başlamıştır. Bu merkezlerden biri de 2008 yılında İstanbul' da kurulan Avrupa Suzuki Derneği'ne bağlı olarak kurulan Suzuki Müzik Eğitimi Derneği' dir. Derneğin amacı, çalgı eğitimi üzerine odaklanmış çalışmalar yapmak, Suzuki öğretmen eğitimi programını gerçekleştirmektir.

Suzuki eğitimini yaygınlaştırmak amacıyla kurulan bu kurumda verilen eğitimlerin felsefesini Tecimer Kasap (2005) çalışmasında şu şekilde ifade etmektedir; Suzuki eğitiminin temel felsefesi “...çocukların müzik yoluyla bir bütün olarak yetiştirilmesidir. Dr. Suzuki bütün hayatı boyunca çocukların müzikal algılama yolu ile güzelliğin farkına varmalarını ve onların insanlara saygı duymalarını sağlamayı hedeflemiştir. Suzuki’nin felsefesine göre, çocuklar gelişim süreci içerisinde kendine güvenen, inanan, zor şeyleri denemeye kararlı, disiplinli, konsantre olabilen, müzikten her zaman hoşlanan, yetenekli ve müziğe karşı duyarlı bireyler olabileceklerdir.

Dünyanın her yerinde tüm Suzuki Derneklerinde olduğu gibi ülkemizde de Suzuki eğitimi bu temel felsefe ışığında çalışmalar yapmakta ve öğrenci yetiştirmektedir. Diğer taraftan dernek öğretmen eğitimi üzerine de çalışmalar yaparak sertifika vermekte ancak bu sertifikayı alan eğitmenler aldıkları sertifikanın kapsamı ölçüsünde Suzuki eğitimi verebilmektedir. Ülkemizde derneğe bağlı olarak Suzuki eğitimi verebilen eğitmenler incelendiğinde, bu eğitimin sadece 41 Suzuki keman eğitimcisi ve 8 Suzuki viyolonsel eğitimcisi ile keman ve viyolonsel alanında verildiği görülmektedir.

Bu bilgiler doğrultusunda, ülkemizde Suzuki yöntemi ve eğitiminin kullanıldığı fakat sadece keman ve viyolonsel eğitimi üzerine bir yapılanma olduğu görülmektedir. Özellikle çalgı eğitimine başlangıç aşamasında büyük önem taşıdığı düşünülen Suzuki yönteminin flüt eğitiminde de önemli bir yer taşıyacağı düşünülmektedir.

Buradan hareketle ilgili alan yazın incelendiğinde Suzuki yöntemini konu alan birçok çalışmaya rastlamak mümkündür (Akpınar, 2009; Aykar, 2014; Brody, 2016; Kuran, 2007; Önder, 2004). Ancak Suzuki yöntemi flüt eğitimi çerçevesinde incelendiğinde literatürde herhangi bir çalışmaya ulaşılamamıştır. Bu kapsamda bu araştırma, Suzuki flüt eğitiminin ülkemizdeki yerinin saptanması ve literatürde bu alanda yapılacak ilk çalışma olması nedeniyle önem taşımaktadır. Araştırmanın önemi doğrultusunda Suzuki yönteminin flüt eğitimi çerçevesinde Suzuki eğitimcileri tarafından değerlendirilmesi amaçlamaktadır. Bu kapsamda ülkemizde Suzuki eğitimi veren eğitimcilerin Suzuki eğitiminin yeri ve önemi konusunda görüşlerini almak için görüşme yapılması planlanırken Avrupa'dan Suzuki eğitimi veren flüt eğitimcileriyle de Suzuki eğitiminin flüt eğitimindeki yeri ve önemi hususunda görüşme yapılması planlanmıştır.

$\mathrm{Bu}$ amaç doğrultusunda araştırmanın problem cümlesi, "Suzuki yöntemi flüt eğitimi çerçevesinde Suzuki eğitimcileri tarafından nasıl değerlendirilmektedir?" olarak belirlenmiştir.

Araştırmada belirlenen problem cümlesi doğrultusunda aşağıda yer alan alt problemlere yanıt aranmıştır.

1.Suzuki yöntemi ülkemizdeki Suzuki eğitimcileri tarafından nasıl değerlendirilmektedir?

2.Suzuki yöntemi flüt eğitimi çerçevesinde ülkemizdeki Suzuki eğitimcileri tarafindan nasıl değerlendirilmektedir?

3.Suzuki yöntemi flüt eğitimi çerçevesinde Avrupa Suzuki Birliği flüt eğitimcileri tarafından nasıl değerlendirilmektedir?

\section{Yöntem}

Araştırmada; nitel araştırma yöntemlerinde kullanılan "Durum Çalışması Deseni”" kullanılmış ve bu doğrultuda yarı yapılandırılmış görüşme formu kullanılarak veriler elde edilmiş̧ir. "Araştırmalarda durum çalışmaları, bir olayı meydana getiren ayrıntıları tanımlamak ve görmek, bir olaya ilişkin olası açıklamaları geliştirmek, bir olayı değerlendirmek, amacıyla kullanılır" (Gall, Borg ve Gall, 1996'dan aktaran Büyüköztürk, Kılıç Çakmak, Akgün, Karadeniz ve Demirel 2008, s. 267).

Araştırma, Suzuki yönteminin flüt eğitimi çerçevesinde Suzuki eğitimcileri tarafindan değerlendirilmesini amaçlamakta olup Suzuki flüt eğitiminin ülkemizdeki yerini saptamak, ülkemizde bu kapsamda yapılan çalışmaları tespit etmek ve incelemek açısından önemli bir çalışmadır. 
Araştırmadaki ilk çalışma grubu; Avrupa Suzuki Birliği'ne (ESA) bağlı olarak 2008 yılında Türkiye'de kurulmuş olan Suzuki Müzik Eğitimi Derneğine bağlı Suzuki eğitimcileridir. Türkiye'de Suzuki Müzik Eğitimi Derneği bünyesinde 41 Suzuki keman eğitimcisi ve 8 Suzuki viyolonsel eğitimcisine ulaşlarak görüşme talebinde bulunulmuştur. Ancak toplamda 9 Keman eğitimcisi, 1 Viyolonsel eğitimcisi geri dönüş yapmış ve bunlardan sadece 7 keman eğitimcisi görüşmeyi kabul etmiştir. Araştırmaya katılan eğitimcilerin demografik özellikleri aşağıda tablo şeklinde verilmiştir.

Tablo 1

Türkiye'deki Suzuki eğitimcilerinin demografik özellikleri

\begin{tabular}{cccc}
\hline Cinsiyet & Ülke & Sahip Olduğu Suzuki Eğitmenlik Sertifikası & Eğitimcinin Uzman Olduğu Enstrüman \\
\hline Kadın & Türkiye & Metot I-II-III & Keman \\
Kadın & Türkiye & Metot I & Keman \\
Kadın & Türkiye & Metot I & Keman \\
Kadın & Türkiye & Metot I & Keman \\
Kadın & Türkiye & Metot I & Keman \\
Kadın & Türkiye & Metot I & Keman \\
Kadın & Türkiye & Metot I-II-III & Keman \\
\hline
\end{tabular}

Araştırmadaki ikinci çalışma grubu ise; Avrupa Suzuki Birliği (ESA) aracılı̆̆ıyla Almanya'dan 15, Fransa'dan 5, İtalya'dan 14, İspanya'dan 9, Belçika'dan 9, Finlandiya'dan 13, İzlanda'dan 1, İrlanda'dan 1, Hollanda'dan 13, Polonya'dan 7, İsveç’ten 14, İsviçre'den 5 ve İngiltere'den 16 Suzuki flüt eğitimcisi olmak üzere toplamda 13 ülkeden 122 Suzuki flüt eğitimcisi olarak belirlenmiş ve görüşme talebinde bulunulmuştur. Ancak toplamda 16 Suzuki flüt eğitimcisi geri dönüş yapmış ve 6'sı görüşme talebini kabul etmiştir. Araştırmaya katılan eğitimcilerin demografik özellikleri aşağıda tablo şeklinde verilmiştir.

Tablo 2

ESA Suzuki eğitimcilerinin demografik özellikleri

\begin{tabular}{cccc}
\hline Cinsiyet & Ülke & Sahip Olduğu Suzuki Eğitmenlik Sertifikası & Ĕgitimcinin Uzman Olduğu Enstrüman \\
\hline Erkek & Belçika & Tüm Suzuki Flüt Metotları & Flüt \\
Kadın & Hollanda & Metot I & Flüt \\
Kadın & Almanya & Metot I & Flüt \\
Kadın & İsveç & Metot II-III & Flüt \\
Kadın & İsveç & Metot I & Flüt \\
Kadın & Almanya & Metot IV-V & Flüt \\
\hline
\end{tabular}

$\mathrm{Bu}$ araştırmanın verileri, yarı yapılandırılmış görüşme tekniği kullanılarak toplanmıştır. Yarı yapılandırılmış görüşme, yapılandırılmış görüşmeden biraz daha esnektir. Bu teknikte, araştırmacı önceden sormayı planladığı soruları içeren görüş̧me protokolünü hazırlar. Buna karşın araş̧ırmacı görüşmenin akışına bağlı olarak değişik yan ya da alt sorularla görüşmenin akışını etkileyebilir ve kişinin yanıtlarını açmasını ve ayrıntı vermesini sağlayabilir (Ekiz, 2003'den aktaran Ergün, Ocak ve Ergün, 2017, s. 2-3).

Araştırmacılar tarafindan, Avrupa Suzuki Birliği flüt eğitimcilerine gönderilmek üzere 6 soruluk ve ülkemizdeki Suzuki eğitimcilerine gönderilmek üzere 9 soruluk iki ayrı görüşme formu oluşturulmuş̧ur. Araştırmada hazırlanan yarı yapılandırılmış görüşme formu, 3 uzman görüşüne sunulmuş, uzman görüşlerinin alınmasından ardından görüş̧me sorularına son şekli verilmiş̧ir.

Araştırmada Avrupa Suzuki Birliğine bağlı flüt eğitimcilerine gönderilmek üzere hazırlanan yarı yapılandırılmış görüşme formunun İngilizce çevrisi yapıldıktan sonra 3 uzman görüşüne sunulmuş, uzman görüşlerinin alınmasının ardından görüşme sorularına son şekli verilmiştir.

Araştırmada yapılan görüşmelerde; etik ilke olarak görüşmenin amacı, gizlilik ilkesi ve isim deşifre edilmeyeceği konusunda araştırma katılımcılarına bilgi verilmiştir. Katılımcıların onayı ile e-posta ve telekonferans üzerinden görüşme gerçekleştirilmiştir. Görüşmeler e-posta üzerinden 6 haftalık bir sürede gerçekleştirilirken telekonferans ile yapılan görüşmeler 30-40 dakika gibi bir sürede gerçekleştirilmiştir.

Araştırmada kullanılan, ülkemizdeki Suzuki eğitimcileri ile yapılan yarı yapılandırılmış görüşme formundaki görüşme soruları ise şu şekildedir;

1.Suzuki eğitimi sizce neden önemlidir?

2.Suzuki eğitimi alan öğrencilerin kazanımları nelerdir?

3.Suzuki eğitimi ile klasik çalgı eğitimi arasında ne gibi farklar var?

4.Suzuki eğitimine ailelerin tutumu ve yaklaşımı nasıldır?

5.Bir Suzuki eğitimcisi olarak neden bu yöntemi, yaklaşımı seçtiniz? Bu yöntemin eğitimci kimliğinize nasıl bir

katkısı var?

6.Suzuki eğitiminin başlangıç aşamasından bahsedebilir misiniz?

7.Ülkemizde hangi alanlarda Suzuki eğitimi veriliyor? 
8.Ülkemizde Suzuki flüt eğitiminin başlatılması için hangi aşamaların tamamlanması ve nasıl bir yol izlenilmesi gerekmektedir?

9.Ülkemizde Suzuki flüt eğitiminin başlamasıyla (öğrenci, aile ve eğitmen açısından) sizce toplumun ne gibi kazanımları olur? Toplumu nasıl etkiler?

Araştırmada kullanılan, Avrupa Suzuki Birliğine bağlı Avrupa'daki Suzuki flüt eğitimcileri ile yapılan yarı yapılandırılmış görüşme formundaki görüşme soruları şu şekildedir;

1.Suzuki flüt eğitimi sizce neden önemlidir?

2.Suzuki flüt eğitiminin başlangıç aşamasından bahsede bilir misiniz?

3.Suzuki flüt eğitimi alan öğrencilerin kazanımları nelerdir?

4.Suzuki flüt eğitimi ile klasik flüt eğitimi arasında ne gibi farklar var?

5.Suzuki flüt eğitiminde ailelerin rolü nedir?

6.Bir flüt eğitimcisi olarak neden bu yöntemle flüt öğretmeyi seçtiniz? Bu yöntemin eğitimci kimliğinize katkısı oluyor mu?

Araştırmada, görüşmeler sonucunda elde edilen verilerin çözümlenmesinde, betimsel analiz kullanılmıştır.

"Betimsel analizde elde edilen veriler, daha önceden belirlenen temalara göre özetlenir ve yorumlanır. Veriler araştırma sorularının ortaya koyduğu temalara göre düzenlenebileceği gibi, görüşme ve gözlem süreçlerinde kullanılan sorular ya da boyutlar dikkate alınarak da sunulabilir. Betimsel analizde, görüşülen ya da gözlemlenen bireylerin görüşlerini çarpıcı bir şekilde yansıtmak amacıyla doğrudan alıntılara sık sık yer verilir" (Yıldırım ve Şimşek, 2011, s. 224).

Katılımcılar, araştırmacı tarafından ülkemizdeki Suzuki eğitimcileri K1, K2, K3 vb. şeklinde isimlendirilirken, Avrupa Suzuki Birliği flüt eğitimcileri ise F1, F2, F3 vb. şeklinde isimlendirilmiştir.

\section{Bulgular}

\subsection{Birinci alt probleme ilişkin bulgular}

"Suzuki yöntemi ülkemizdeki Suzuki eğitimcileri tarafindan nasıl değerlendirilmektedir?" alt problemine ilişkin eğitimcilere 7 soru sorulmuş ve sorulan sorulara eğitimcilerin verdikleri cevaplar tablolar halinde gösterilmiştir.

Tablo 3

Birinci alt problemin birinci sorusuna ilişkin eğitimci görüşleri

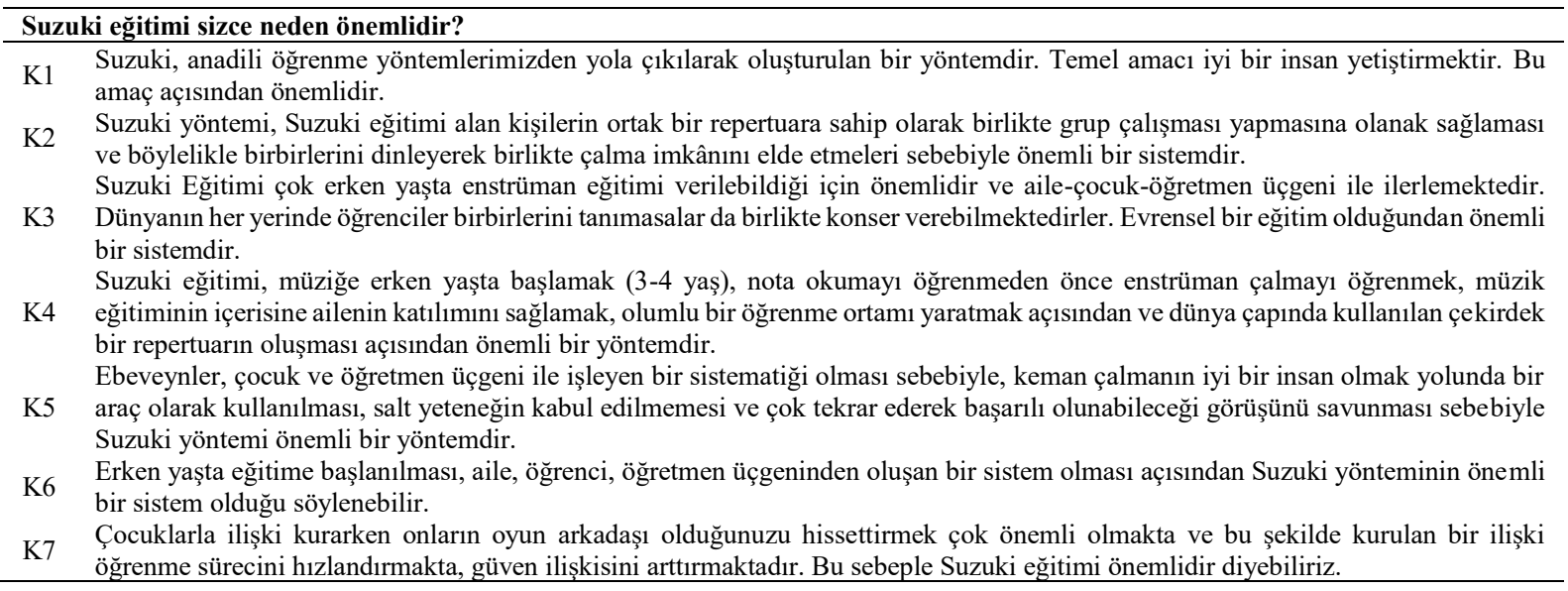

Eğitimcilere "Suzuki eğitimi sizce neden önemlidir?" sorusu sorulmuştur. Katılımcılar, Suzuki eğitimin erken yaşta enstrüman eğitimi verilebildiği için önemli olduğunu (K3, K4, K6), aile-çocuk-öğretmen üçgeni ile sistematik bir biçimde ilerlediğini ve evrensel bir repertuara sahip olması dolayısıyla tüm Dünya'daki çocukların beraber müzik yapmalarına olanak sunduğunu ( $\mathrm{K} 3, \mathrm{~K} 4, \mathrm{~K} 5, \mathrm{~K} 6$,), eğitiminin temel amacının pozitif insan bilinci(iyi insan) yetiştirmek olduğunu(K1,K5), çocuklara nasıl yaklaşılması ve nasıl enstrüman öğretilmesine dikkat eden bir sistem olduğunu (K7) belirtmişlerdir. 
Tablo 4

Birinci alt problemin ikinci sorusuna ilişkin eğitimci görüşleri

Suzuki eğitimi alan öğrencilerin kazanımları nelerdir?

K1 En önemli iki şey çocukların erken yaşta sahne korkusunu yenmeleri ve sistematik ilerleme kaydetmeleri diyebiliriz.

K2 Suzuki eğitiminin başlangıcında nota öğretiminin olmaması motivasyon ve konsantrasyon sağlamaktadır. Eser dinlemelerinin yapılması ve ezbere çalınması kulak gelişimine de katkı sağlamaktadır.

Öğrenciler çok küçük yaştan itibaren dinleme ve taklit etme yetilerini geliștirerek enstrüman çalmayı öğrenmektedirler. Suzuki'nin

K3 "Yetenek Gelişimi ve Anadil Metodu” yöntemleri sayesinde müzik kulakları ve yetenekleri küçük yaştan itibaren gelişmektedir. Bu sayede ülkemizdeki konservatuar eğitimine nazaran çok daha erken yaşta enstrüman çalmaya başlamakla beraber ilerde başarılı olabilmektedirler.

K4 Suzuki eğitimi, öğrencideki sorumluluk bilincinin gelişmesine katkı sağlayarak sabrı ve bol tekrarı benimseyen çalışma yöntemiyle, öğrencinin çalışarak ve sabrederek bașarıya ulaşacağı düșüncesini pekiștirmektedir.

Çocuklar derslerde olumsuz hiçbir şey duymadığı için derslere keyifli ve istekli bir şekilde gelmektedirler. Çocuklar, ebeveynler

K5 sayesinde bol bol kayıtları da dinlediği için hem kulak gelişimini gerçekleştirmekte hem de çok daha hazır bir biçimde derslere gelmektedirler.

K6 Suzuki eğitimi çok tekrara dayanan bir sistem olduğu için; ögrencinin her alanda disipline olmasını ve bunu hayat bilinci haline getirmesini sağlamaktadır.

K7 Suzuki metoduyla yetiştirdiğim öğrencilerimle birlikte daha çok eğlendiğimizi, daha çok güldüğümüzü ve derslerden daha mutlu ayrıldıklarını gözlemliyorum.

Eğitimcilere "Suzuki eğitimi alan öğrencilerin kazanımları nelerdir?” sorusu sorulmuştur. Katılımcılar, öğrencilerde kulak gelişimi ile beraber taklit yeteneğini (ezbere çalması) geliştirdiğini (K3, K5), öğrencilere motivasyon ve konsantrasyon sağladığını (K2), yöntemin belli bir sistematikle ilerlemesi sebebiyle hızlı gelişimin gözlendiğini ve çocukların sahne korkusunu erken yaşta yendiklerini (K1), sabretmek ve sorumluluk bilincinin gelişmesine katkı sağladığını öğrencinin bunu hayatına yansıttığını (K4, K6), derslere mutlu gelip mutlu ayrıldıklarını (K5, K7) belirtmişlerdir.

Tablo 5

Birinci alt problemin üçüncü sorusuna ilişkin eğitimci görüşleri

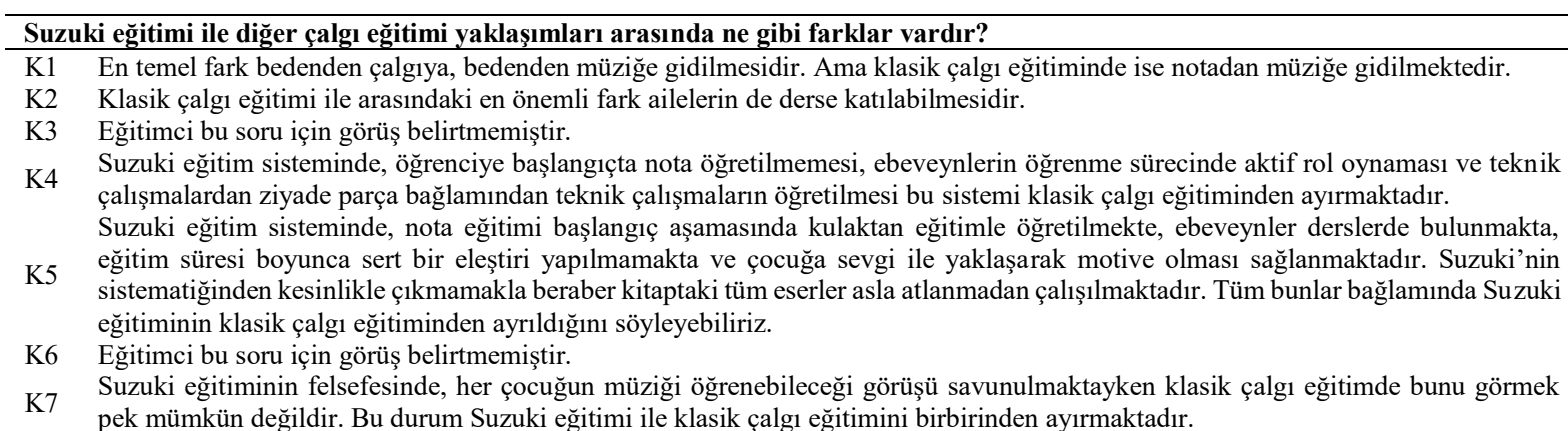

Eğitimcilere "Suzuki eğitimi ile diğer çalgı eğitimi yaklaşımları arasında ne gibi farklar vardır?" sorusu sorulmuştur. Katılımcılar bu yöntemde ailelerin derslerde bulunmasının öğrencilerin motivasyonunu arttırdığını (K2, K4, K5), klasik sistemde notadan müziğe gidilirken Suzuki’de bedenden müziğe gidildiğini (K1), başlangıçta nota eğitimi olmadan çalgı eğitimine başlandığını (K4, K5), eğitim sürecinde her zaman motive etme ve sevgiyle yaklaşmanın önemli olduğunu ve kesinlikle sert bir eleştiri ile öğrenciye yaklaşılmadığını (K5), Suzuki sistematiğinden çıkılmadan eser atlanılmadan eğitime devam etme kuralından çıkılmadığını (K5), bu sistemde her çocuğun müzik öğrenebileceğini (K7) belirtmişlerdir.

Tablo 6

Birinci alt problemin dördüncü sorusuna ilişkin eğitimci görüşleri

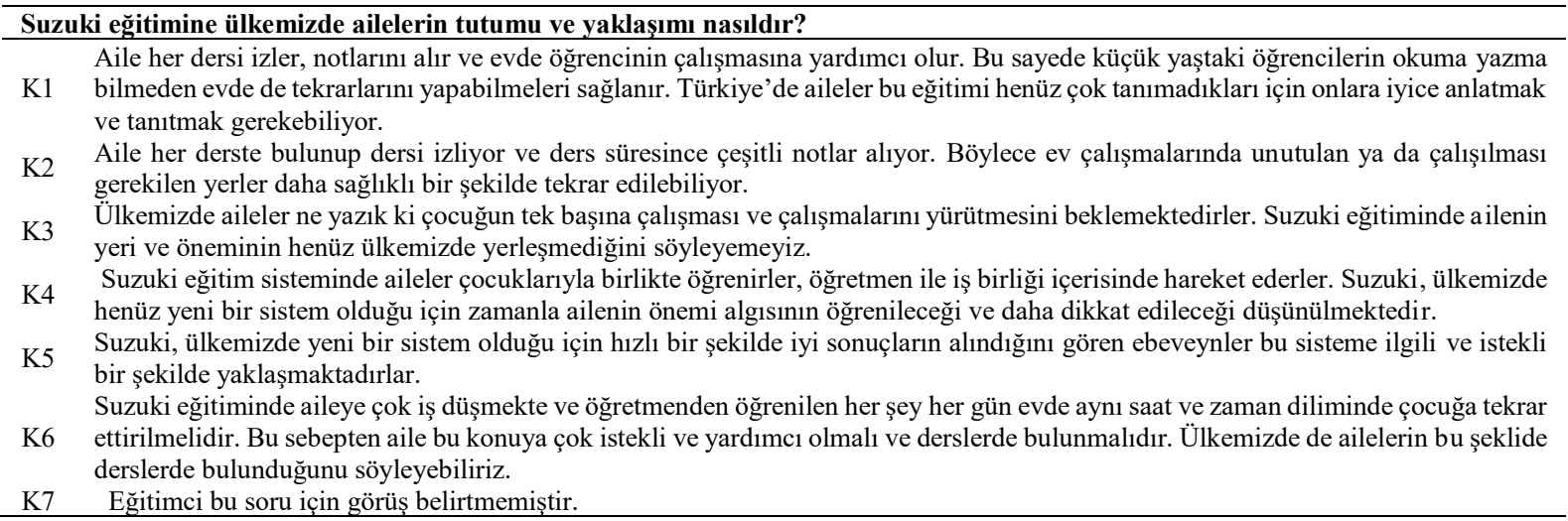


Eğitimcilere "Suzuki eğitimine ülkemizde ailelerin tutumu ve yaklaşımı nasıldır?" sorusu sorulmuştur. Katılımcılar, ailenin derslerde bulunup notlar almasının çocuğun bir sonraki derse hazırlanma sürecinde çalışmalarını nasıl yapacağı hususunda yol gösterici olması açısından önemli oluğunu (K1, K2, K4, K6), Suzuki eğitiminin ülkemizde yeni bir sistem olması nedeniyle sistemin ailelere iyice anlatılması gerektiğini (K3, K4), sistemi deneyimleyen ailelerin çok istekli ve mutlu bir şekilde bu sisteme yaklaştığını (K5) belirtmişlerdir.

Tablo 7

Birinci alt problemin beşinci sorusuna ilişkin eğitimci görüşleri

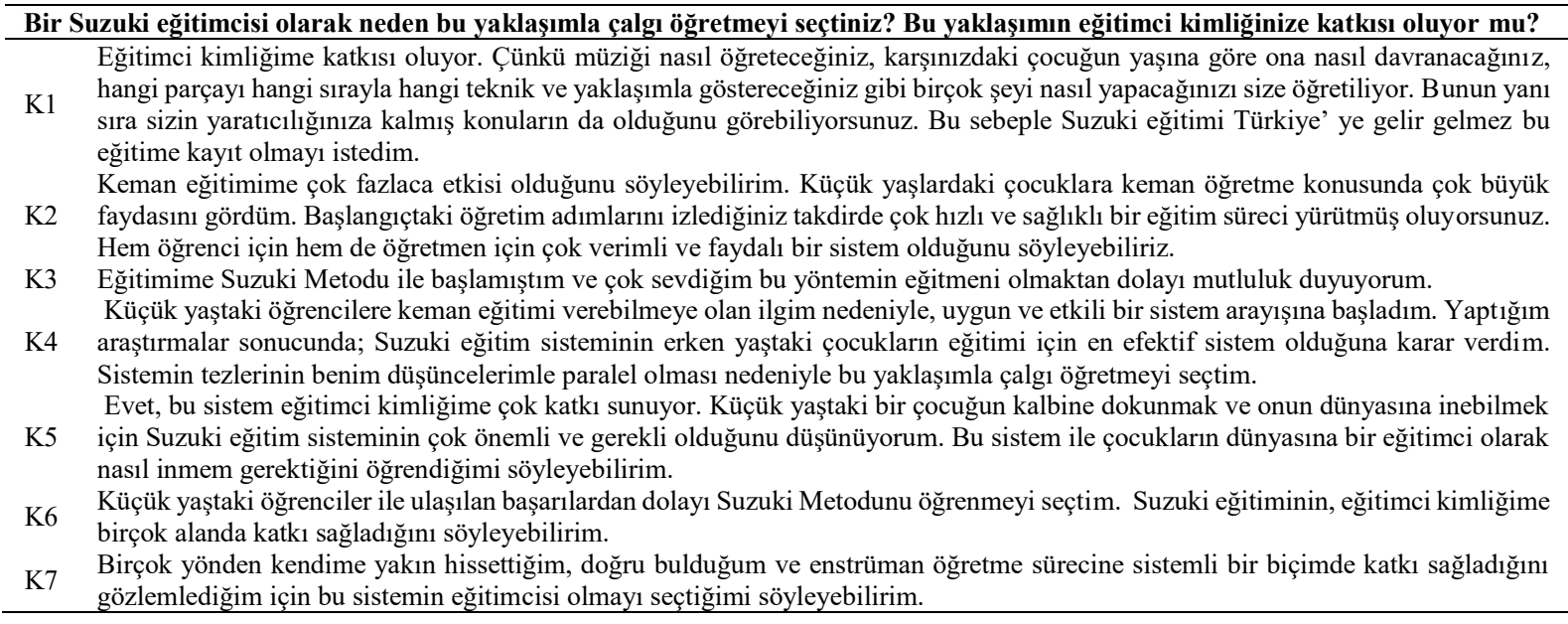

Eğitimcilere "Bir Suzuki eğitimcisi olarak neden bu yaklaşımla çalgı öğretmeyi seçtiniz? Bu yaklaşımın eğitimci kimliğinize katkısı oluyor mu?" sorusu sorulmuştur. Katılımcılar, Suzuki eğitim sisteminin erken yaştaki çocukların çalg1 eğitiminde kullanılan en etkili sistemlerden biri olduğunu (K1, K2, K4, K6), Suzuki eğitiminin sistematiğinden, derslerin pozitif geçmesinden, öğretmenin yaratıcılığının sürdürülebilir olmasından dolayı bu sistemi tercih ettiklerini (K1, K2, K4), Suzuki eğitimi ile keman öğrenmiş bir eğitimci olarak bu sistemin öğretmeni olmayı tercih ettiğini (K3), bu sistemin eğitimci kimliğine çok fazla katk1 sağladığını $(\mathrm{K} 1, \mathrm{~K} 2, \mathrm{~K} 5, \mathrm{~K} 6)$ belirtmişlerdir.

Tablo 8

Birinci alt problemin altıncı sorusuna ilişkin eğitimci görüşleri

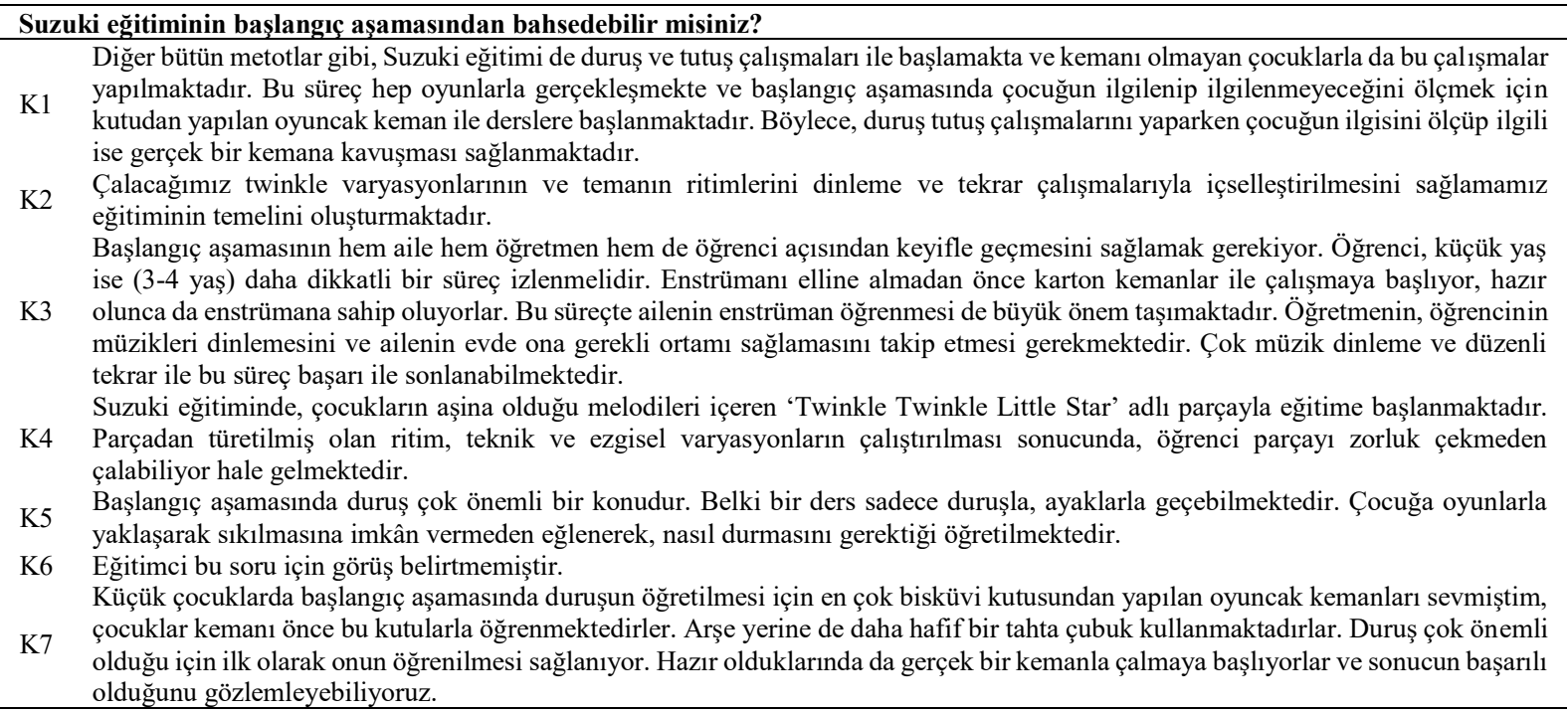

Eğitimcilere "Suzuki eğitiminin başlangıç aşamasından bahsedebilir misiniz?” sorusu sorulmuştur. Katılımcılar, öncelikle duruş ve postür çalışmalarının çok önemli olduğu ve ilk olarak çalışıldığını (K1, K3, K5, K7), enstrümanı ellerine almadan önce kartondan yapılan maket kemanlarla çalışıldığını ve bu durumun gerçek kemana geçme aşamasında motivasyonu arttırdığını, arşe yerine de bir çubuk ile çalışıldığını (K1, K3, K7), çocuğun derslerden önce öğretmenin belirttiği başlangıç eseri olan Twinkle gibi müzikleri dinleyerek derslere geldiğini $(\mathrm{K} 2, \mathrm{~K} 3, \mathrm{~K} 4)$ ve başlangıç aşamasında bu unsurların oldukça önemli olduğunu belirtmişlerdir. 
Tablo 9

Birinci alt problemin yedinci sorusuna ilişkin eğitimci görüşleri

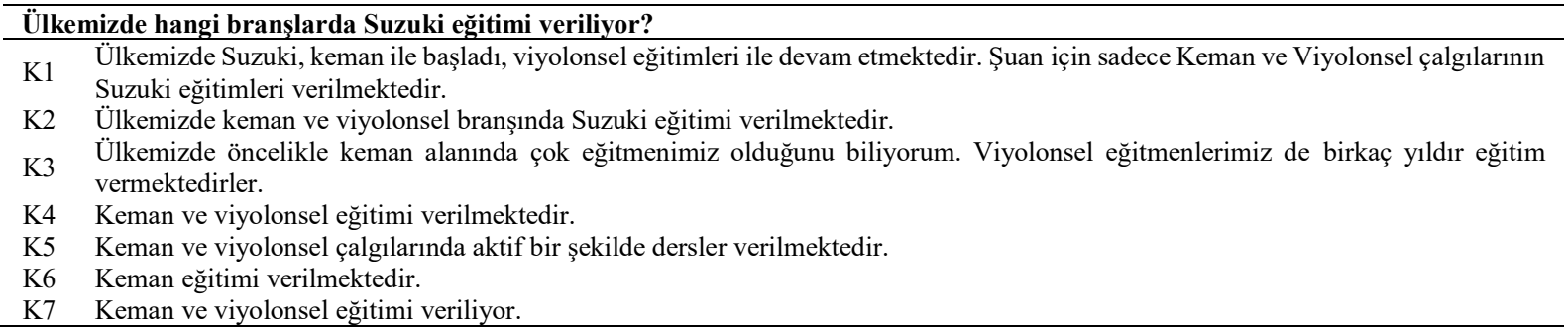

Eğitimcilere "Ülkemizde hangi branşlarda Suzuki eğitimi veriliyor?” sorusu sorulmuştur. Katılımcılar, keman ve viyolonsel eğitimlerinin verildiğini $(\mathrm{K} 1, \mathrm{~K} 2, \mathrm{~K} 3, \mathrm{~K} 4, \mathrm{~K} 5, \mathrm{~K} 6, \mathrm{~K} 7)$ belirtmişlerdir.

\section{2. İkinci alt probleme ilişkin bulgular}

"Suzuki yöntemi flüt eğitimi çerçevesinde ülkemizdeki Suzuki eğitimcileri tarafından nasıl değerlendirilmektedir?" alt problemine ilişkin eğitimcilere 2 soru sorulmuş ve sorulan sorulara eğitimcilerin verdikleri cevaplar tablo şeklinde gösterilmiştir.

Tablo 10

İkinci alt problemin birinci sorusuna ilişkin eğitimci görüşleri

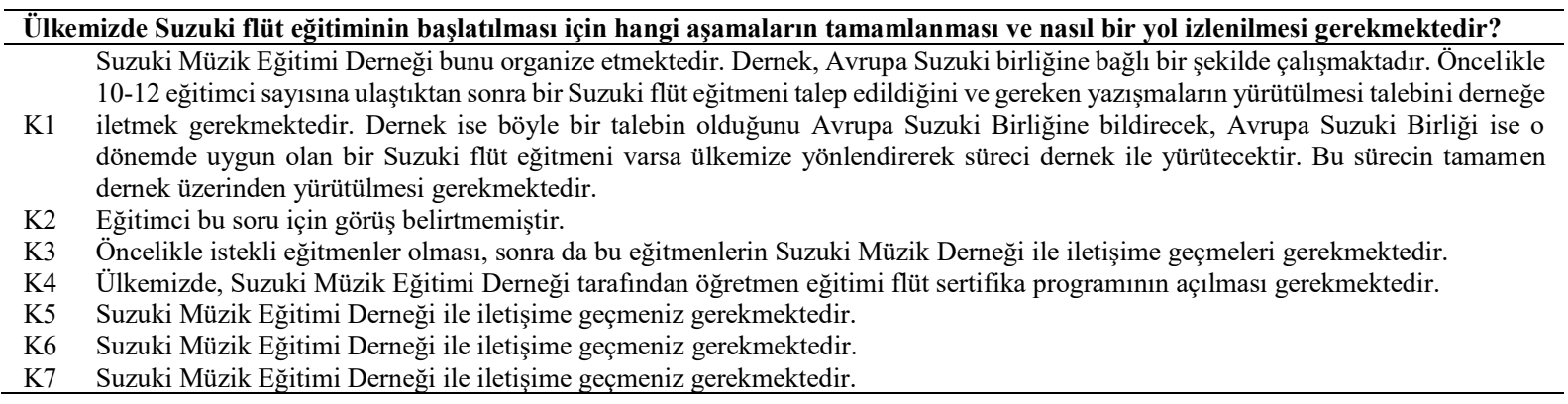

Eğitimcilere "Ülkemizde Suzuki flüt eğitiminin başlatılması için hangi aşamaların tamamlanması ve nasıl bir yol izlenilmesi gerekmektedir?" sorusu sorulmuştur. Katılımcılar ülkemizde flüt eğitiminin başlaması için öncelikle Suzuki müzik eğitimi derneği ile iletişime geçilmesi gerektiğini (K1, K2, K3, K4, K5, K6, K7), bu aşamadan sonra derneğin flüt eğitimi kursu açmak için 10-12 flüt eğitimcisinden oluşan bir çalışma sınıfını oluşturarak Avrupa Suzuki Birliğinden ülkemize bir Suzuki flüt eğitmeni getirmek için talepte bulunması gerektiğini ve sistemin bu şekilde işlediğini (K1, K4) belirtmişlerdir.

Tablo 11

İkinci alt problemin ikinci sorusuna ilişkin eğitimci görüşleri

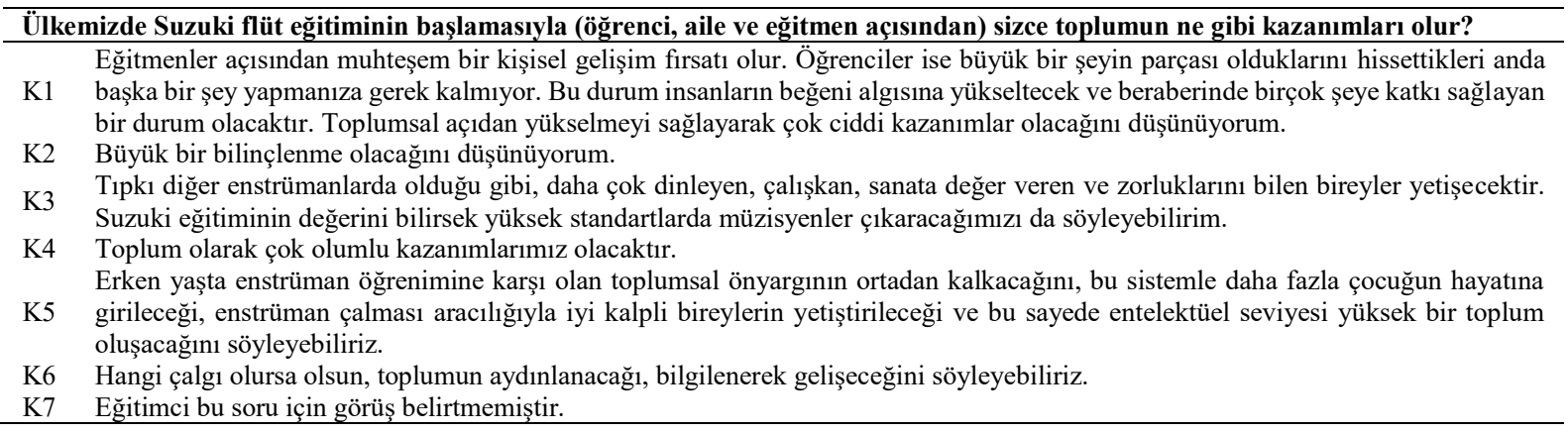

Eğitimcilere "Ülkemizde Suzuki flüt eğitiminin başlamasıyla (öğrenci, aile ve eğitmen açısından) sizce toplumun ne gibi kazanımları olur?" sorusu sorulmuştur. Katılımcılar, ülkemizde Suzuki flüt eğitiminin başlamasının eğitimciler için çok iyi bir kişisel gelişim firsatı olacağını (K1), diğer enstrümanlarda olduğu gibi, daha çok dinleyen, daha çok çalışan gençler yetiştirerek sanata değer veren ve sanatın zorluklarını bilen bireyler yetiştirmiş olacağımızı (K3), erken yaşta verilen enstrüman eğitiminin keman ve viyolonselde olduğu gibi flüt eğitiminde de aynı olumlu etkiyi sağlayacağını (K6), toplumsal açıdan çok fazla kazanımların olacağını ve toplumun bilinç düzeyinin artacağını (K1, K2, K4, K6) belirtmişlerdir. 


\section{3. Üçüncü alt probleme ilişkin bulgular}

"Suzuki yöntemi flüt eğitimi çerçevesinde Avrupa Suzuki Birliği flüt eğitimcileri tarafından nasıl değerlendirilmektedir?" alt problemine ilişkin Avrupa'daki Flüt eğitimcilerine 6 soru sorulmuş ve sorulan sorulara eğitimcilerin verdikleri cevaplar tablo şeklinde gösterilmiştir.

Tablo 12

Üçüncü alt problemin birinci sorusuna ilişkin flüt eğitimcilerinin görüşleri

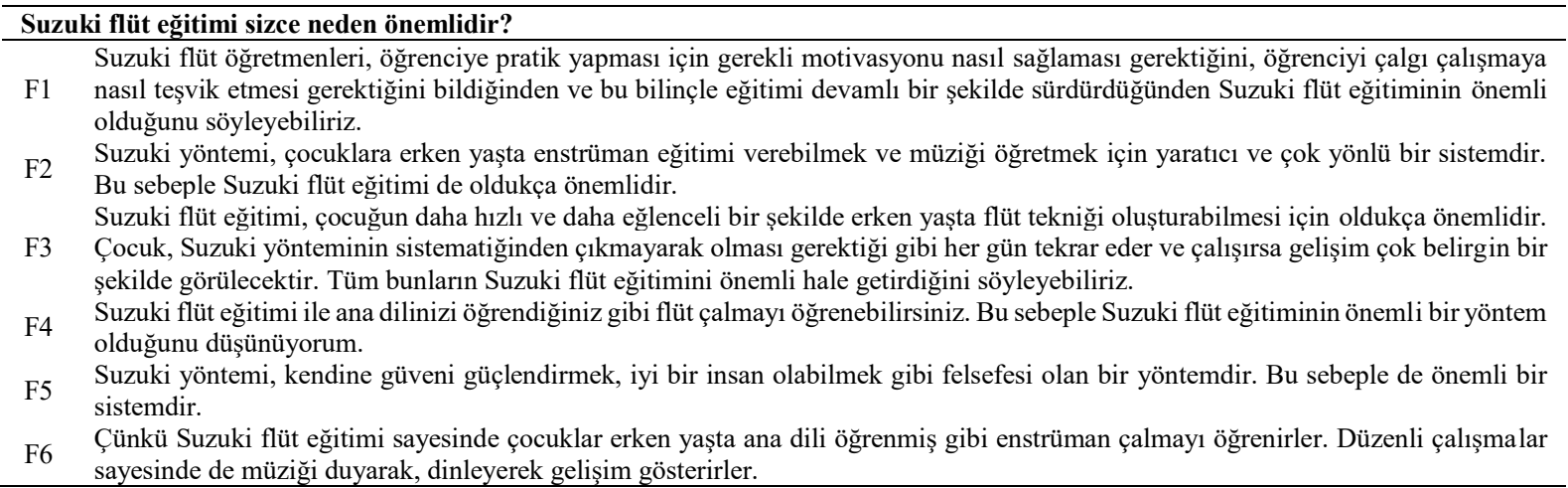

Eğitimcilere "Suzuki flüt eğitimi sizce neden önemlidir?" sorusu sorulmuştur. Katılımcılar, Suzuki flüt öğretmenlerinin öğrenci ile nasıl iletişim kurması gerektiğini bildiği ve dersleri bilinçli bir şekilde sürdürebildiği için Suzuki flüt eğitiminin önemli olduğunu (F1), çocuklara erken yaşta enstrüman eğitimi verebilmek ve müziği öğretebilmek için Suzuki flüt eğitiminin önemli olduğunu (F2), Suzuki flüt eğitiminin, çocuğun erken yaşta hızlı bir şekilde keyif alarak flüt tekniği oluşturabilmesine olanak sağladığı için önemli olduğunu (F3), çocukların Suzuki flüt eğitimi ile erken yaşta anadillerini öğrendikleri gibi flüt çalmayı öğrenebildikleri için bu yöntemin önemli olduğunu (F4, F6), Suzuki yönteminin iyi insan olabilmek, kendine güveni güçlendirmek gibi bir felsefesi olduğu için önemli olduğunu (F5) belirtmişlerdir. Flüt eğitiminin keman ve viyolonselde olduğu gibi flüt eğitiminde de aynı olumlu etkiyi sağlayacağını (F6), toplumsal açıdan çok fazla kazanımların olacağını ve toplumun bilinç düzeyinin artacağını (F1, F2, F4, F6) belirtmişlerdir.

Tablo 13

Üçüncü alt problemin ikinci sorusuna ilişkin flüt eğitimcilerinin görüşleri

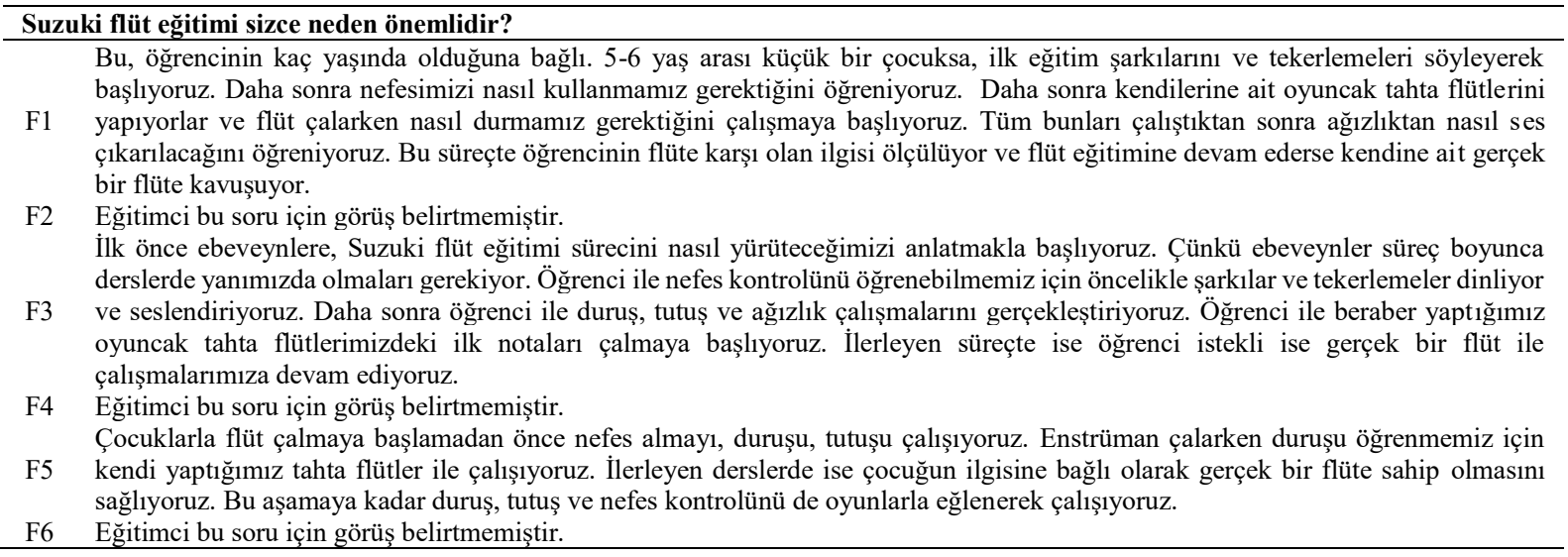

Eğitimcilere "Suzuki flüt eğitiminin başlangıç aşamasından bahsede bilir misiniz?” sorusu sorulmuştur. Katılımcılar, ilk olarak ebeveynlere süreci iyice anlattıklarını, eğitim süreci boyunca ailelerle beraber dersleri yürüttüklerini, çocuklarla nefes kontrolünü öğrenebilmek için şarkılar ve tekerlemeler seslendirdiklerini, flüt için doğru duruş ve tutuş çalışmalarının öğretmen ve öğrencinin beraber yapmış olduğu oyuncak flütler ile gerçekleştirildiğini, ilerleyen süreçte ise öğrencinin seviyesine göre gerçek flütler ile eğitime devam edildiğini (F1, F3, F5) belirtmişlerdir. 
Tablo 14

Üçüncü alt problemin üçüncü sorusuna ilişkin flüt eğitimcilerinin görüşleri

\begin{tabular}{cl}
\hline Suzuki flüt eğitimi ile diğer çalgı eğitimi eğitimi yaklaşımları arasında ne gibi farklar vardır? \\
\hline F1 & $\begin{array}{l}\text { Suzuki yöntemi ile çocuk, küçük yaşta kulakla öğrenip, dinler ve taklit eder. Grup derslerinde arkadaşları ile eğlenir, oyunlar oynar } \\
\text { ve bunları yaparken bir enstrüman çalmayı öğrenir. Suzuki flüt eğitimi bu yönüyle klasik çalgı eğitiminden farklılık göstermektedir. } \\
\text { Suzuki flüt eğitiminde başlangıçamasındayken nota kullanılmaz, ebeveynler derse katılır, bireysel ve grup dersleri vardır, herkes } \\
\text { aynı repertuar üzerinde çalışır (böylece dünyadaki diğer Suzuki öğrencileriyle aynı repertuarı çalabilirler). Her çocuğun yılda birkaç } \\
\text { kez ulusal ve uluslararası Suzuki çalışmalarına katılma şansı vardır. Fakat tüm bunlar klasik çalgı eğitiminde yoktur. }\end{array}$ \\
F2 & $\begin{array}{l}\text { Suzuki yönteminde ebeveynler derslerde daima bulunuyorlar. Suzuki flüt eğitimi ile daha erken yaşta flüt eğitimine başlamak } \\
\text { mümkün olmakla beraber süreci başlangıçta nota kullanmadan yürütüyorsunuz. }\end{array}$ \\
F4 & $\begin{array}{l}\text { Suzuki flüt eğitiminde başlangıç aşamasıonda nota kullanılmıor. Dünya'daki tüm Suzuki flüt öğrencileri ile aynı repertuar aynı sistem } \\
\text { ile çalışılıyor. }\end{array}$ \\
Geleneksel Flüt eğitiminde çocuklar, her zaman yeni bir parça öğrenir ve eski parçaları unutur. Çocuklar, Suzuki yöntemiyle kulaktan \\
çalmayı öğrenirler, geleneksel yöntemlerde ise nota enstrüman ile çalmayı öğrenirler. Suzuki yönteminde öğretmen, çocuk ve \\
ebeveyn arasında önemli bir üçgen ve işbirliği vardır. Klasik yöntemlerde sadece Öğretmen ve Çocuk arasında bir işbirliği vardır. \\
Çocuklar Suzuki yönteminde daha iyi seviyelerde flüt çalabiliyorlar ve küçük yaşta müziğe daha fazla duygu katabiliyorlar.
\end{tabular}

Eğitimcilere "Suzuki flüt eğitimi ile diğer çalgı eğitimi yaklaşımları arasında ne gibi farklar vardır?" sorusu sorulmuştur. Katılımcılar, Suzuki yöntemiyle çocukların kulaktan çalmayı öğrendiklerini (F1, F2, F4, F5), Grup dersleri ile enstrüman çalmayı öğrenmeleri yönüyle bu yöntemin farklılığını (F1, F2), Suzuki flüt eğitiminde ebeveynlerin derslerde bulunduklarını (F2, F3, F5), Dünya'daki tüm Suzuki flüt öğrencileri ile ortak repertuar üzerinden belli bir sistem ile ilerleyip çalışıldığını (F2, F4), Suzuki flüt eğitimi ile daha erken yaşta flüt eğitimine başlama şansı elde edebilmesi ve çocukların Suzuki eğitimi ile daha iyi seviyelerde flüt çalmaları yönüyle farklılaştıklarını (F3, F4), belirtmişlerdir.

Tablo 15

Üçüncü alt problemin dördüncü sorusuna ilişkin flüt eğitimcilerinin görüşleri

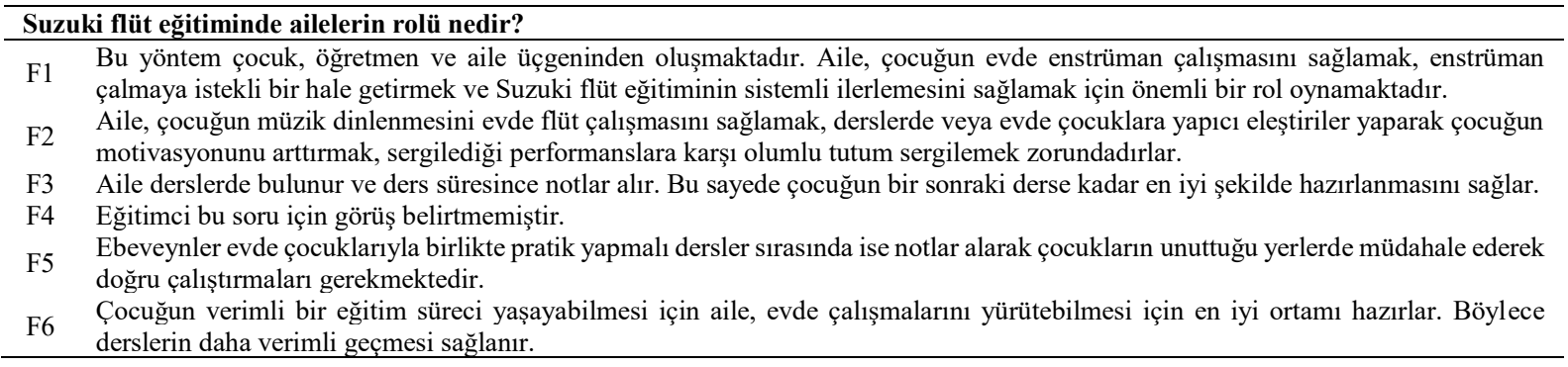

Eğitimcilere "Suzuki flüt eğitiminde ailelerin rolü nedir?" sorusu sorulmuştur. Katılımcılar, ailenin çocuğun evde enstrüman çalmasını sağlaması gerektiğini ve çocuğun motivasyonunun artması için ailenin yapıcı eleştiriler yaparak çocuğa karşı olumlu tutum sergilemesi gerektiğini (F1, F2), ailenin çocukla beraber evde pratik yapmas1 ve ders anında notlar alarak çocuğun unuttuğu yerleri çalıştırması gerektiğini (F5) ailenin derslerde bulunarak not alması ve böylece çocuğu bir sonraki derse kadar en iyi şekilde hazırlaması gerektiğini ve ailenin çocuğa evde çalışabilmesi için uygun ortamı yaratması gerektiğini (F3, F6) belirtmişlerdir.

Tablo 16

Üçüncü alt problemin beşinci sorusuna ilişkin flüt eğitimcilerinin görüşleri

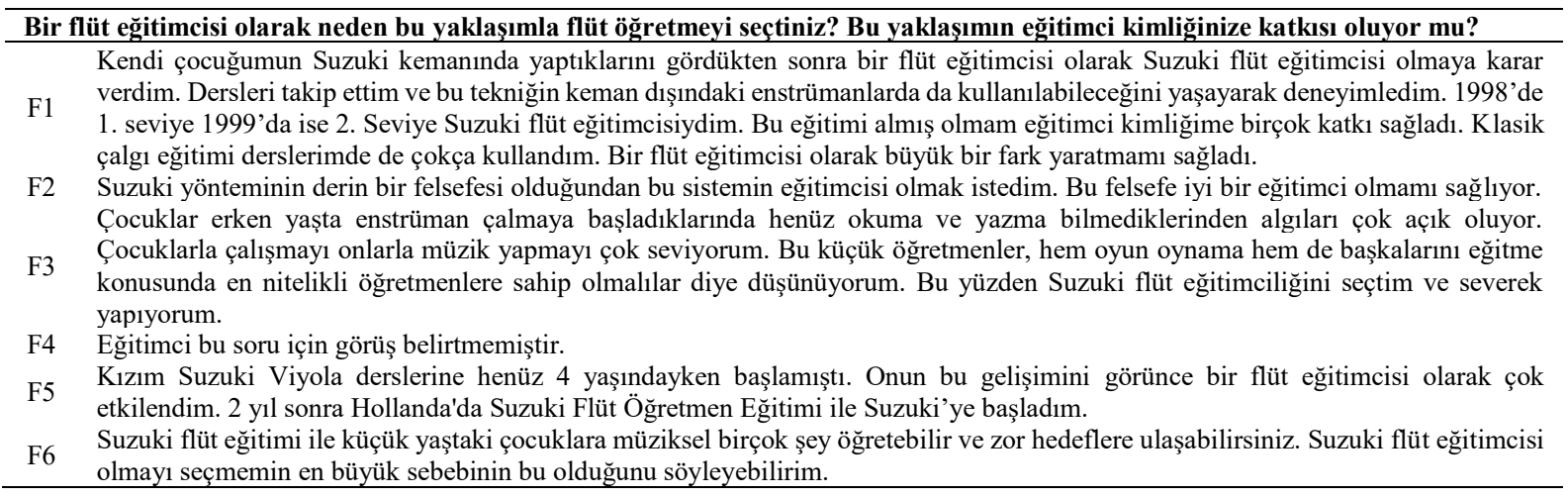

Eğitimcilere "Bir flüt eğitimcisi olarak neden bu yaklaşımla flüt öğretmeyi seçtiniz? Bu yaklaşımın eğitimci kimliğinize katkısı oluyor mu?" sorusu sorulmuştur. Katılımcılar, Eğitimci kimliklerine çok büyük fayda sağladığını (F1, F5), Suzuki flüt eğitimi yönteminin felsefesi yönüyle daha iyi bir eğitimci olmak adına katkı sağladığını (F2), daha nitelikli bir öğretmen olmak istediklerini ve küçük çocuklarla çalışmayı sevdikleri için bu yöntemi seçtiklerini (F6, F3), belirtmişlerdir. 
Tablo 17

Üçüncü alt problemin altıncı sorusuna ilişkin flüt eğitimcilerinin görüşleri

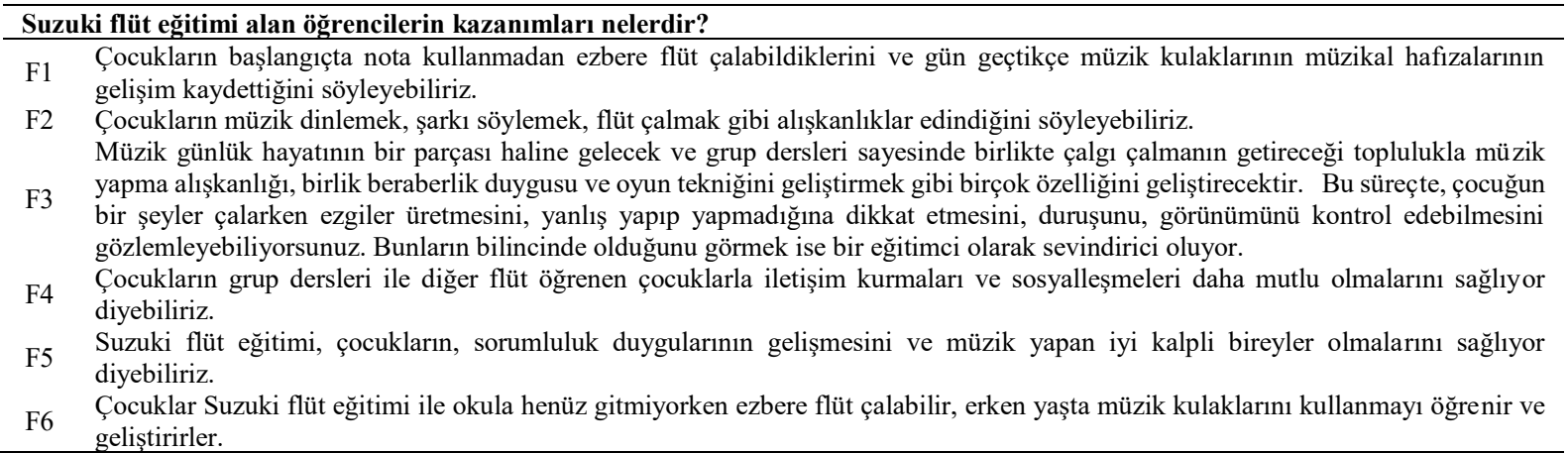

Eğitimcilere "Suzuki flüt eğitimi alan öğrencilerin kazanımları nelerdir?” sorusu sorulmuştur. Katılımcılar, çocukların erken yaşta nota kullanmadan ezbere flüt çalabildiklerini ve bu durumun müzik kulaklarının gelişimine katkı sağladığını (F1, F6), çocukların Suzuki flüt eğitimi ile flüt çalma, şarkı söyleme, müzik dinleme gibi alışkanlıklar edindiklerini (F2), çocukların grup dersleri sayesinde iletişim becerilerinin arttığını ve daha sosyal bireyler olduklarını (F4), çocukların grup dersleri sayesinde toplu bir biçimde müzik yapma duygusunu hissettiklerini ve flüt çalarken kendi kontrollerini sağlayabilecek bilinç düzeyine ulaşmış olduklarını (F3) belirtmişlerdir.

\section{Tartışma, sonuç ve öneriler}

Suzuki yönteminin flüt eğitimi çerçevesinde Suzuki eğitimcileri tarafindan değerlendirilmesinin amaçlanmasıyla yola çıkılan çalışmanın sonuçları şu şekildedir;

Araştırmanın birinci alt problemi olan "Suzuki yöntemi ülkemizdeki Suzuki eğitimcileri tarafından nasıl değerlendirilmektedir?” sorusu kapsamında eğitimcilerin görüşleri değerlendirildiğinde ulaşılan veriler şu şekilde sıralanmıştır;

Katılımcılar, Suzuki eğitiminin erken yaşta enstrüman eğitimi verilebildiği için önemli olduğunu, bu yöntemin aile-çocuk-öğretmen üçgeni ile sistematik bir biçimde ilerlediğini ve evrensel bir repertuara sahip olması dolayısıyla tüm Dünya'daki çocukların beraber müzik yapmalarına olanak sunduğunu, eğitiminin temel amacının pozitif insan bilinci (iyi insan) yetiştirmek olduğunu belirtmişlerdir. Katılımcıların tüm görüşleri doğrultusunda Suzuki yönteminin önemli bir yöntem olduğu sonucuna ulaşılmıştır. Literatür incelendiğinde Sever (2019)'in "Suzuki Öğretmen Yetiştirme Sisteminin İncelenmesi” adlı çalışmasında da Suzuki sisteminin önemi ve uygulama aşamalarındaki yapısı anlatılmıştır. Araştırmanın sonuçları Sever (2019)'in çalışmasıyla paralellik göstermektedir.

Suzuki eğitimi alan öğrencilerin, erken yaşta müzik kulaklarının ve ezber yeteneklerinin geliştiği, yöntemin sistematik ilerlemesi sebebiyle öğrencilerin hızlı bir gelişim kaydettikleri ve bununla beraber çocukların erken yaşta sahne korkularını yendikleri eğitimcilerin gözlemleri doğrultusunda belirtilmiştir. İlgili literatür incelendiğinde Suzuki eğitimi ile öğrencilerin birçok kazanım elde ettiğine yönelik çalışmalara rastlamak mümkündür. Bu çalışmalardan biri; Özçelik (2010)'un 'Suzuki Yetenek Eğitimi ve Bartok Mikrokosmos Yöntemleriyle Özengen Piyano Eğitiminde Yoğunlaşma Becerisi” adlı çalışmasıdır. Çalışmada Suzuki eğitimi ile piyano eğitimi alan öğrencilerin yoğunlaşma becerilerinin geliştiği sonucuna ulaşılmıştır. Bu sonuç araştırmada elde edilen veri ile paralellik göstermektedir.

Eğitimcilere "Suzuki eğitimi ile diğer çalgı eğitimi yaklaşımları arasında ne gibi farklar vardır?" sorusu sorulmuştur. Katılımcılar bu yöntemde ailelerin derslerde bulunmasının öğrencilerin motivasyonunu arttırdığını, klasik sistemde notadan müziğe gidilirken Suzuki'de bedenden müziğe gidildiğini, Suzuki sistematiğinden çıkılmadan eser atlanılmadan eğitime devam etme kuralından çıkılmadığını, bu sistemde her çocuğun müzik öğrenebileceğini ve dolayısıyla diğer çalgı eğitimi yaklaşımlarından oldukça ayrıştığını belirtmişlerdir. Eğitimcilerin görüşleri doğrultusunda diğer çalgı eğitimi yaklaşımları içerisinde özellikle temel felsefesi yönüyle diğer yaklaşımlardan ayrıştığı düşünülen Suzuki yöntemi kulaktan eğitim ile yola çıkarak tüm çocukların evrensel bir repertuara sahip olması hedeflemektedir. Böylelikle tüm Dünya'daki çocukların hiçbir kaygı taşımadan beraber müzik yapmalarına olanak sunmasının bu yöntemi farklı kıldı̆̆ı söylenebilir.

Suzuki eğitiminde ailelerin; derslerde bulunarak notlar almasının çocuğun bir sonraki derse hazırlanma sürecinde çalışmalarını nasıl yapacağı hususunda yol gösterici olması açısından önemli olduğu eğitimcilerin gözlemleri doğrultusunda belirtilmiştir. Bu görüş ve gözlemler doğrultusunda "Suzuki eğitimine ülkemizdeki ailelerin tutumu ve yaklaşımı oldukça olumludur" denilebilir. İlgili literatür incelendiğinde Dittgen (2018)'in; "Suzuki Yönteminde Ailenin Yeri ve Önemi” adlı çalışmasında da benzer görüşlere yer verilmiştir. Dittgen ailelerin derslerde bulunma 
sürecinin eğitime oldukça katkı sağladığını ve ailelerin bu süreçte oldukça mutlu ve istekli olduklarını belirtmektedir. Bu bakımdan elde edilen sonuç literatürle paralellik göstermektedir.

Eğitimcilere "Bir Suzuki eğitimcisi olarak neden bu yaklaşımla çalgı öğretmeyi seçtiniz? Bu yaklaşımın eğitimci kimliğinize katkısı oluyor mu?" sorusu sorulmuştur. Katılımcılar, Suzuki eğitim sisteminin erken yaştaki çocukların çalgı eğitiminde kullanılan en etkili sistemlerden biri olduğunu, Suzuki eğitiminin sistematiğinden, derslerin pozitif geçmesinden, öğretmenin yaratıcılığının sürdürülebilir olmasından dolayı bu sistemi tercih ettiklerini ve bu sistemin eğitimci kimliklerine çok fazla katkı sağladığını belirtmişlerdir.

Eğitimcilere "Suzuki eğitiminin başlangıç aşamasından bahsedebilir misiniz?" sorusu sorulmuştur. Katılımcılar; çocuğun derslerden önce öğretmenin belirttiği müzikleri dinleyerek derslere gelmesi gerektiği, gerçek enstrümanı eline almadan önce arşe yerine kullanılan oyuncak bir çubuk, kartondan yapılan maket bir keman ile duruş ve tutuş çalışmalarını gerçekleştirdiğini belirtmişlerdir. Katılımcıların ortak fikri olan bu durumdan yola çıkılarak öğrencilerin gerçek enstrümanı hak etmek için daha istekli çalıştıkları ve başlangıç aşamasında yaratılan bu durumun öğrencilerin motivasyonlarını arttırdığı düşünülebilir.

Eğitimcilere "Ülkemizde hangi branşlarda Suzuki eğitimi veriliyor?" sorusu sorulmuştur. Katılımcıların görüşleri doğrultusunda ise ülkemizde Suzuki eğitiminin sadece keman ve viyolonsel çalgılarında verildiği ve çalışmanın çıkış ve noktası olan flüt eğitimi çerçevesinde ülkemizde hiçbir çalışmanın yapılmadığı sonucuna ulaşılmıştır. Bu durum ülkemizde Suzuki flüt eğitimine yönelik yapılan çalışmaların eksikliğini ortaya koymaktadır.

Araştırmanın ikinci alt problemi olan "Suzuki yöntemi flüt eğitimi çerçevesinde ülkemizdeki Suzuki eğitimcileri tarafindan nasıl değerlendirilmektedir?" sorusu kapsamında eğitimcilerin görüşleri değerlendirildiğinde ulaşılan veriler şu şekilde sıralanmıştır;

Eğitimcilere "Ülkemizde Suzuki flüt eğitiminin başlatılması için hangi aşamaların tamamlanması ve nasıl bir yol izlenilmesi gerekmektedir?” sorusu sorulmuştur. Katılımcılar; ülkemizde flüt eğitiminin başlaması için öncelikle Suzuki müzik eğitimi derneği ile iletişime geçilmesi gerektiği, bu aşamadan sonra derneğin flüt eğitimi kursu açmak için 10-12 flüt eğitimcisinden oluşan bir çalışma sınıfını oluşturarak Avrupa Suzuki Birliğinden ülkemize bir Suzuki flüt eğitmeni getirmek için talepte bulunması gerektiğini ve yurt dışından gelen flüt eğitimcisinin verdiği Suzuki eğitimini başarıyla tamamlayan ve sertifika almaya hak kazanan eğitimcilerin Suzuki flüt öğretmenliği yapabileceğini ve sistemin kısaca bu şekilde işlediğini belirtmişlerdir. Tüm bu görüşler doğrultusunda ülkemizde Suzuki flüt eğitimin başlayabilmesi, gerçekleştirilebilmesi için bu aşamaların tamamlanması gerektiği sonuçlarına ulaşılmıştır.

Ülkemizde Suzuki flüt eğitiminin başlamasıyla (öğrenci, aile ve eğitmen açısından) toplumun kazanımlarının, eğitimciler için çok iyi bir kişisel gelişim firsatı olacağı ve diğer enstrümanlarda olduğu gibi daha çok dinleyen ve çalışan bireyler yetiştirerek sanata değer veren, sanatın zorluklarını bilen bireylerin yetiştirilmesine katkı sağlayacağı eğitimciler tarafından belirtilmiştir. Aynı zamanda bu durumun toplumun bilinç düzeyini artacağı eğitimcilerin ortak görüşüdür. Buradan hareketle Suzuki yönteminin felsefesi, sistematiği ve işleyişi ile topluma büyük bir fayda sağlayacağı ve mutlu bireylerin çoğalacağı söylenebilir. Sever (2019)'un; "Suzuki Öğretmen Yetiştirme Sisteminin İncelenmesi" adlı betimsel çalışmasında da benzer görüşlere yer verilmiştir. Sever, "Suzuki yöntemi ile eğitimciler kendilerini geliştirme firsatı bulurken öğrencilerin de farklı öğretmenler ile çalışma firsatı yakaladığını belirtmiştir.

Araştırmanın üçüncü alt problemi olan "Suzuki yöntemi flüt eğitimi çerçevesinde Avrupa Suzuki Birliği flüt eğitimcileri tarafından nasıl değerlendirilmektedir?" sorusu kapsamında eğitimcilerin görüşleri değerlendirildiğinde ulaşılan veriler şu şekilde sıralanmıştır;

Eğitimcilere "Suzuki flüt eğitimi sizce neden önemlidir? sorusu sorulmuştur. Katılımcılar, bu yöntemde çocukların erken yaşta anadillerini öğrendikleri gibi flüt çalmayı öğrenebilmesi ve çocuğun erken yaşta hızlı bir şekilde keyif alarak flüt tekniği oluşturabilmesine olanak sağlanması, Suzuki yönteminin iyi insan olabilmek, kendine güveni güçlendirmek gibi bir felsefesi olması yönüyle oldukça önemli olduğunu belirtmişlerdir. Diğer taraftan katılımcılar Suzuki flüt öğretmenlerine öğrenci ile nasıl iletişim kurması gerektiğinden nasıl bir öğretme stratejisi izleyeceğine kadar verilen bir eğitim sürecinin olması yönüyle bu yöntemin önemli olduğunu ifade etmişlerdir. Bu bağlamda Suzuki flüt eğitiminin felsefesi, eğitimin başlangıç aşamasının farklılığı ve verilen eğitmen eğitimi ile oldukça önemli bir çalgı eğitimi yöntemi olduğu söylenebilir.

Eğitimcilere "Suzuki flüt eğitiminin başlangıç aşamasından bahsedebilir misiniz?" sorusu sorulmuştur. Katılımcılar, ilk olarak ebeveynlere süreci iyice anlattıklarını, eğitim süreci boyunca ailelerle beraber dersleri yürüttüklerini, nefes kontrolünü öğretebilmek için çocuklarla şarkılar ve tekerlemeler seslendirdiklerini, flüt için doğru duruş ve tutuş çalışmalarının öğretmen ve öğrencinin beraber yapmış olduğu oyuncak flütler ile gerçekleştirildiğini, ilerleyen süreçte ise öğrencinin seviyesine göre gerçek flütler ile eğitime devam edildiğini belirtmişlerdir. 
Suzuki flüt eğitimi alan öğrencilerin erken yaşta nota kullanmadan ezbere flüt çalabildikleri ve bu durumun müzik kulaklarının gelişimine katkı sağladığı, çocukların Suzuki flüt eğitimi ile flüt çalma, şarkı söyleme, müzik dinleme gibi alışkanlıklar edindikleri, grup dersleri sayesinde iletişim becerilerinin arttığı ve daha sosyal bireyler oldukları, çocukların grup dersleri sayesinde toplu bir biçimde müzik yapma duygusunu hissettikleri ve flüt çalarken kendi kontrollerini sağlayabilecek bilinç düzeyine ulaşmış oldukları eğitimcilerin gözlemleri doğrultusunda belirtilmiştir. Suzuki flüt eğitimcileri öğrencilerin bu yöntem sayesinde birçok kazanımları olduğunu ifade etmişlerdir.

Eğitimcilere "Suzuki flüt eğitimi ile diğer çalgı eğitimi yaklaşımları arasında ne gibi farklar vardır?" sorusu sorulmuştur. Katılımcılar, Suzuki yöntemiyle çocukların kulaktan çalmayı öğrendiklerini, grup dersleri ile enstrüman çalmayı öğrenmeleri yönüyle bu yöntemin farklılığını, Suzuki flüt eğitiminde ebeveynlerin derslerde bulunduklarını, Dünya'daki tüm Suzuki flüt öğrencileri ile ortak repertuar üzerinden belli bir sistem ile ilerleyip çalışıldığını, Suzuki flüt eğitimi ile daha erken yaşta flüt eğitimine başlama şansı elde edebilmesi ve çocukların Suzuki eğitimi ile daha iyi seviyelerde flüt çalmaları yönüyle farklılaştıklarını belirtmişlerdir. Eğitimcilerin görüşleri doğrultusunda diğer çalgı eğitimi yaklaşımları içerisinde özellikle temel felsefesi yönüyle diğer yaklaşımlardan ayrıştığı düşünülen Suzuki flüt eğitiminin kulaktan eğitim ile yola çıkarak tüm çocukların evrensel bir repertuara sahip olması hedeflemektedir. Böylelikle tüm Dünya'daki çocukların hiçbir kaygı taşımadan beraber flüt çalmalarına, müzik yapmalarına olanak sunmasının bu yöntemi farklı kıldığı söylenebilir. İlgili literatür incelendiğinde Dickerson (2011)'ın “Flute Teachıng The Suzuki Way” adlı çalışmasına rastlamak mümkündür. Bu çalışmada Suzuki flüt eğitiminin ortak repertuar üzerinden belli bir sistemle ilerlediği dünyadaki tüm Suzuki flüt eğitimi öğrencilerinin uygun ortam sağlandığında aynı eseri çalabilme olanaklarının olduğu belirtilmektedir.

Eğitimcilere "Suzuki flüt eğitiminde ailelerin rolü nedir?" sorusu sorulmuştur. Katılımcılar, çocuğun motivasyonunun artması için ailenin yapıcı eleştiriler yaparak çocuğa karşı olumlu tutum sergilemesi gerektiğini, ailenin çocukla beraber evde pratik yapması ve ders anında notlar alarak çocuğun unuttuğu yerleri çalışmasında destek olmasının önemli olduğunu ve ailenin çocuğa evde çalışabilmesi için uygun ortamı yaratması gerektiğini belirtmişlerdir. Böylelikle eğitimcilerin görüşleri doğrultusunda Suzuki flüt eğitiminde ailenin rolünün çok önemli olduğunu söyleyebiliriz. İlgili literatür incelendiğinde Charles (2010)'un "A supplementary book of chiese music for Suzuki flute student" adlı çalışmasına rastlamak mümkündür bu çalışmada Suzuki flüt eğitiminin başarısının aile-öğrenci-öğretmen işbirliği ile başarıya ulaşacağı belirtilmektedir.

"Bir flüt eğitimcisi olarak neden bu yaklaşımla flüt öğretmeyi seçtiniz? Bu yaklaşımın eğitimci kimliğinize katkısı oluyor mu?" sorusu eğitimcilere sorulmuştur. Katılımcılar; Suzuki eğitimi felsefesinin daha iyi bir insan daha iyi bir eğitimci olmak adına kendilerine katkı sağladığını, bu yöntemi daha nitelikli bir öğretmen olmak istedikleri ve küçük çocuklarla çalışmayı sevdikleri için seçtiklerini belirtmişlerdir.

Sonuç olarak; temel amacı iyi insan yetiştirmek olan Suzuki eğitimi hem öğrenciler açısından hem de eğitimi verecek olan eğitmenler açısından felsefesi, sistematiği ve işleyişi ile diğer çalgı eğitimi yöntemlerinden ayrışmaktadır. Nota eğitimi olmadan anadili öğrenme yöntemlerimizden yola çıkılarak kulaktan eğitimle belirli bir sistematik içerisinde başlayan Suzuki eğitiminin en temel özelliği ortak bir repertuarın ortak bir strateji ile bu eğitimin sertifikasını almış ve eğitmen eğitimini tamamlamış öğretmenler tarafından aynı şekilde veriliyor olmasıdır. Diğer taraftan eğitimin aile-çocuk-öğretmen üçgeni ile ilerlemesi, eğitimi alan tüm öğrencilerin evrensel bir repertuara sahip olmasıyla istedikleri zaman hiçbir kaygı taşımadan birlikte müzik yapabilmeleri diğer bir deyişle erken yaşta sahne korkusunu yenmeleri bu yöntemi farklı k1lmaktadır. Ülkemizde sadece keman ve viyolonsel eğitimleri verilen Suzuki yöntemi Avrupa'da ve tüm dünyada flüt ve diğer birçok enstrümanda verilmektedir. Özellikle çalgı eğitimine başlangıç aşamasında büyük önem taşıdığı düşünülen Suzuki yönteminin flüt eğitiminde de önemli bir yer taşıyacağı düşünülmektedir. Bu doğrultuda bu araştırma ile Suzuki flüt eğitiminin ülkemizdeki yerinin saptanması ve ileriki dönemlerde Suzuki yönteminin flüt eğitimi çerçevesinde de yaygınlaștırılmasına yönelik olarak bu alandaki eksikliğe dikkat çekilmesi amaçlanmıştır. Ülkemizde Suzuki flüt eğitiminin başlaması hem eğitmenler hem de bu eğitimden faydalanacak öğrenciler açısından mükemmel bir eğitim fırsatı olacaktır. Ayrıca flüt eğitiminin ve diğer tüm enstrümanlardaki Suzuki eğitiminin yaygınlaşmasıyla toplumsal açıdan çok ciddi kazanımlar sağlanacağı diğer bir ifadeyle en temelinde başarıyı tatmış mutlu çocukların, mutlu ailelerin ve dolayısıyla mutlu ve iyi bir toplumun oluşacağı Suzuki eğitimcilerinin ortak görüşüdür.

Buradan hareketle araştırmada Suzuki flüt eğitiminin ülkemizde verilmediği ve aynı zamanda Suzuki flüt eğitimine yönelik akademik herhangi bir çalışma yapılmadı̆̆ Suzuki flüt eğitiminin ve ülkemizde diğer enstrüman eğitimlerinde verilen Suzuki eğitimlerinin olumlu sonuçları ve eğitimcilerin görüşleri değerlendirildiğinde Suzuki flüt eğitiminin ülkemizde başlatılması ve yaygınlaştırılması gerektiği düşünülmektedir. Bu doğrultuda Suzuki flüt eğitiminin ülkemizde başlatılmasına dikkat çekmeye yönelik olarak başka çalışmaların yapılması, yapılacak olan çalışmaların farklı değişkenlerle incelenmesi, Suzuki flüt eğitmeni eğitimlerinin başlatılmasına yönelik olarak girişimlerde bulunmak adına çalışmaların yapılması önerilebilir. 


\section{Kaynakça}

Akpınar, U. (2009). Suzuki Piano School Volume I' okul öncesi dönem piyano eğitiminde başlangıç metodunun hedef ve hedef davranışlar bakımından incelenmesi (Yüksek lisans tezi). Gazi Üniversitesi Eğitim Bilimleri Enstitüsü, Ankara. YÖK tez veri tabanından erişildi (Tez No. 239265).

Aykar A. (2014). Suzuki yönteminin Türk halk ezgileri kullanılarak başlangıç gitar eğitimine uygulanabilirliği (Yüksek lisans tezi). Necmettin Erbakan Üniversitesi Eğitim Bilimleri Enstitüsü, Konya. YÖK tez veri tabanından erişildi (Tez No. 407543)

Büyüköztürk, Ş., Kılıç Çakmak, E., Akgün, Ö.E., Karadeniz, Ş., \& Demirel, F. (2008). Bilimsel Araştırma Yöntemleri (Geliştirilmiş 2. Bask1). Ankara: Pegem Akademi.

Brody, Z. S. (2016). Suzuki yetenek eğitimi felsefesine kısa bir bakış. Sanat \& Tasarım Dergisi, 10, 79-88. Erişim adresi: http://dergipark.gov.tr/download/article-file/275064

Charles, N. M. (2010). A supplementary book of Chinese music for the Suzuki flute student (Doctoral Thesis). The Ohio State University, Ohio-ABD. Erişim adresi: https://etd.ohiolink.edu/!etd.send file?accession= osu1275340340\&disposition $=$ online

Dittgen, J. Y. (2018) Suzuki yönteminde ailenin yeri. Sahne ve Müzik Araştırma Dergisi, 6, 13-20. Erişim adresi: http://dergipark.gov.tr/smead/issue/34898/386978

Dickerson, D. (2011). Flute teaching the Suzuki way. 30(2), 43-47. Erişim adresi: http://eds.a.ebscohost.com/eds/ Citations/FullTextLinkClick?sid=f89a7f1f-7314-4ab5-a95e-fa3a9a2560df@sdc-vsessmgr03\&vid=1\&id= pdf FullText

Ekiz, D. (2003). Eğitimde araştırma yöntem ve metotlarına giriş. Ankara: Anı Yayıncılık.

Ergün, S., Ocak, İ., \& Ergün, E. (2017). Fen bilimleri öğretmenlerinin nano teknoloji hakkındaki görüşleri. Ĕgitim ve Öğretim Araştırmaları Dergisi, 6(4), 272-282. Erişim adresi: http://www.jret.org/FileUpload/ks281142/ File/32.selcen_suheyla_ergun.pdf

Gall, M., Borg, W., \& Gall, J. P. (1996). Educational research an introduction (6. Baskl). USA: Longman Publisher.

Tecimer Kasap, B. (2005). Suzuki metodu okulu. İn̈nü Üniversitesi Eğitim Fakültesi Dergisi, 10, 115-128. Erişim adresi: https://www.pegem.net/Akademi/3-8281-Suzuki-Piyano-Okulu-Metodu.aspx

Kuran, E. N. (2007). Suzuki metodu ve Türkiye'deki konservatuvar öncesi müzik eğitimi (Yüksek lisans tezi). Anadolu Üniversitesi Sosyal Bilimler Enstitüsü, Eskişehir. YÖK tez veri tabanından erişildi (Tez No. 221537).

Önder, Ü. (2004). Suzuki keman eğitimi başlangıç metodundaki etütlerin devinişsel hedef ve hedef davranışlar bakımından analiz edilmesi (Yüksek lisans tezi). Gazi Üniversitesi Eğitim Bilimleri Enstitüsü, Ankara. YÖK tez veri tabanından erişildi (Tez No. 144993).

Özçelik, A. Ö. (2010). Suzuki yetenek eğitimi ve Bartok mikrokosmos yöntemleriyle özengen piyano eğitiminde yoğunlaşma becerisi. Uludă̆ Eğitim Fakültesi Dergisi, 23(2), 643-661. Erişim adresi: http://dergipark.gov.tr/uefad/issue/16692/173502

Sever, G. (2019). Suzuki öğretmen yetiştirme sisteminin incelenmesi. Kastamonu Ĕ̆itim Dergisi, 27(1), 37-46. doi: https://doi.org/10.24106/kefdergi.2247

Şeker, S. S. (2005). 7-11 yaş grubunda Orff öğretisi destekli keman eğitiminde başlangıç metodu oluşturulmasına ilişkin bir çalışma (Yüksek Lisans Tezi). Dokuz Eylül Üniversitesi Eğitim Bilimleri Enstitüsü, İzmir. YÖK tez veri tabanından erișildi (Tez No. 162646).

Yalçınkaya, B., Eldemir, A. C., \& Sönmezöz, F. (2014). Müzik öğretmeni adaylarının bireysel çalgı dersine yönelik tutumlarının değerlendirilmesi. International Periodical for The Languages, Literature and History of Turkish or Turkic 9(2), 1583-1595. Erișim adresi: http://www.academia.edu/download/33748918/ 1316628746_89YalcinkayaBegum-vd-sos-1583-1595.pdf

Yıldırım, A., \& Şimşek, H. (2011). Sosyal bilimlerde nitel araştırma yöntemleri (8. Baskı Tıpkı Basım). Ankara: Seçkin Yayıncılık 